\title{
Sustainable feed resources for optimizing broiler performance in tropical countries
}

\author{
Anjas Asmara Samsudin ${ }^{1 *}$, Mamat Hamidi Kamalludin ${ }^{1}$, and Abdul Razak Alimon ${ }^{2}$ \\ ${ }^{1}$ Department of Animal Science, Faculty of Agriculture, Universiti Putra Malaysia, 43400 Serdang, \\ Selangor, Malaysia \\ ${ }^{2}$ Faculty of Animal Science, Universitas Gadjah Mada, Indonesia
}

\begin{abstract}
Soybean meal and grain corn are feedstuffs that normally used as the main ingredients in poultry feeds as a source of protein and energy in tropical countries. The availability of these feedstuffs for broiler nutrition nowadays is becoming more competitive. Thus, food security, especially in the developing countries, would be susceptible. Currently, efforts are being made to use alternative feedstuffs as a sustainable feed resources to substitute portion of soybean meal and grain corn in poultry diets due to their high price since both of the raw material were imported. In Malaysia, usage of PKC is common in ruminant diets, but limited in the non-ruminant diets especially in poultry diets due to the high fiber content of PKC. Several works have been conducted to increase the nutritional contents of PKC as one of the measures to reduce and/or eliminate the constraints of utilizing PKC in poultry diets. The method used to achieve this target is either through physical, chemical, biological or combination of these treatments. This paper discusses the use of PKC as the sustainable feed resources that can be incorporated in the poultry feeds. Hence, emphasis should be given to improve nutritional values of PKC in order to reduce feeding cost of poultry.
\end{abstract}

\section{Introduction}

Under tropical environment, poultry production especially broiler is encumbered by several constraints which preventing them to achieve their full genetic potential. The shortage and high feed price, limited availability of raw material such as grain corns and soybean, has been a big challenge to this sector, since feed still represents a major operational cost in producing the birds. The consumption of poultry products, appears to increase in the tropical countries since it is considered as one of the cheaper protein source. This has demanded the grains to be imported as the main poultry feedstuffs which causing an increased in production cost since the raw materials (corn grain and soy bean) are not suitable to grow in the tropic. The increase of world population year by year would definitely create a competition between human and the poultry industry since both of these group used the grains are the main feed ingredients.

*Corresponding author: anjas@upm.edu.my 
In addition, there is an increasing demand to produce a biofuel from plants, especially from corn grain. This further poses a severe food security risk, especially in the tropical region. Rapid development of the poultry industry in tropical countries has created a situation of overdependence on the conventional feedstuffs. Currently, efforts are being made to use alternative energy and protein sources to substitute soybean and corn in monogastric industry. The soybean meal is usually used as a main protein source in poultry diet ingredient. Due to price of this feedstuff is quite expensive and unaffordable, some poultry farmers have used a non-traditional feed ingredients that can substitute a certain amount of soybean meal in the diets. Those ingredients are insect meal (e.g. black soldier fly larvae and earthworm), algae, azolla and single-cell protein.

In many developing tropical countries, a huge amount of alternative feedstuffs, considered as agricultural by-products such as rice bran, copra meal and palm kernel cake (PKC) is widely available. For instance in Malaysia, the used of PKC as animal feed has been widely practiced especially in ruminant industry. However, it's used as part of poultry diet ingredient has some limitations. It contained a non-starch polysaccharides (NSPs) such as mannan and xylan as well as secondary metabolite that limits the intake and digestibility of the feeds in the broiler [1].

\subsection{Palm oil industry in Malaysia}

Malaysia have a vast agriculture land that is planted with palm oil tree and this has produced an abundant amount of PKC, which is considered an agricultural industrial waste derived from the extraction process of oil from palm fruits. An increased in the oil palm planted area has been recorded from 5.23 million ha in 2013 to 5.86 million ha in 2020 [2]. This is mainly due to an increase of planted area in Sarawak and Sabah. However, Sarawak is still the largest oil palm planted area (1.58 million ha), followed by Sabah (1.54 million ha) (Table 1) [2].

Table 1. Oil palm planted area in Malaysia [2]

\begin{tabular}{|l|c|c|c|c|c|c|}
\hline State & $\begin{array}{c}\text { Mature } \\
(\mathrm{Ha})\end{array}$ & $\%$ & $\begin{array}{c}\text { Immature } \\
(\mathrm{Ha})\end{array}$ & $\%$ & Total (Ha) & $\%$ \\
\hline Johor & 688,291 & 92.9 & 52,537 & 7.1 & 740,828 & 12.6 \\
\hline Kedah & 80,210 & 89.3 & 9,572 & 10.7 & 89,782 & 1.5 \\
\hline Kelantan & 131,768 & 78.6 & 35,831 & 21.4 & 167,599 & 2.9 \\
\hline Melaka & 51,672 & 91.7 & 4,689 & 8.3 & 56,361 & 1.0 \\
\hline Negeri Sembilan & 173,490 & 91.1 & 16,972 & 8.9 & 190,462 & 3.2 \\
\hline Pahang & 702,163 & 89.8 & 80,084 & 10.2 & 782,247 & 13.3 \\
\hline Perak & 362,557 & 90.0 & 39,211 & 10.0 & 391,768 & 6.7 \\
\hline Perlis & 689 & 99.3 & 5 & 0.7 & 694 & 0.0 \\
\hline Pulau Pinang & 12,540 & 97.7 & 289 & 2.3 & 12,829 & 0.2 \\
\hline Selangor & 113,911 & 90.0 & 12,614 & 10.0 & 126,525 & 2.2 \\
\hline Terengganu & 148,244 & 83.0 & 30,384 & 17.0 & 178,628 & 3.0 \\
\hline Peninsular Malaysia & $2,455,535$ & 89.7 & 282,188 & 10.3 & $2,737,723$ & 46.7 \\
\hline Sabah & $1,344,608$ & 87.1 & 198,446 & 12.9 & $1,543,054$ & 26.3 \\
\hline Sarawak & $1,431,600$ & 90.3 & 152,920 & 9.7 & $1,584,520$ & 27.0 \\
\hline Malaysia & $5,231,743$ & 89.2 & 633,554 & 10.8 & $5,865,297$ & 100 \\
\hline
\end{tabular}


Apart producing palm oil, the plantations of oil palm industry in Malaysia also produce a number of useful by-products such as PKC, palm kernel shells (PKS), empty fruit bunches, (EFB), oil palm fronds (OPF), palm oil mill effluent (POME; also called sludge and decanter cake), oil palm trunks (OPT), and palm press fibre (PPF) throughout the year and this guarantees their availability as livestock feed ingredients.

Although large quantities of PKC produced from this industry are readily available as feed for livestock, but the use of PKC is usually limited to the ruminant sector, due to coarse texture, high fibre content, and presence of a non-starch polysaccharides (NSP) such as $58 \%$ mannan, $12 \%$ cellulose and $4 \%$ xylan [3]. Monogastric animals such as poultry and swine have limitation in utilizing this feedstuff because of the anatomical structure of their gastrointestinal system that does not have the capability to produce enzymes that can efficiently digest fibrous feed material. The digestion of NSP fractions in the PKC especially mannans that is hard and crystalline tends to be more variable due to lack of digestive enzymes and their predilection to create a viscous environment in the intestinal lumen $[4,5]$.

The palm kernel cake supplies both energy and protein, but it is looked upon more as a protein source. The crude protein (CP) content of PKC varies between 10.0 to $19.8 \%$ [6,7]. Furthermore, PKC also contains high crude fibre (CF) ranging between 13 to $20 \%$ (Table 2) [8] and this contributes to the low digestibility in poultry.

Table 2. Nutrient composition of PKC [8]

\begin{tabular}{|l|c|}
\hline Ingredients & Content (\%) \\
\hline Dry matter & $88.0-94.5$ \\
\hline Crude fibre (CF) & $13.0-20.0$ \\
\hline Crude protein (CP) & $14.5-19.6$ \\
\hline Ash & $3.0-12.0$ \\
\hline Ether extract & $5.0-8.0$ \\
\hline Calcium & $0.2-0.3$ \\
\hline Phosphorus & $0.48-0.7$ \\
\hline ME, MJ/Kg & $6.50-7.50$ \\
\hline Amino acid, g/16 g N & \\
\hline Lysine & 2.68 \\
\hline Methionine & 1.75 \\
\hline
\end{tabular}

Several studies have reported that supplementation of exogenous enzymes such as mannanase, cellulase and xylanase on diets containing PKC could improve its nutritive value making it more available for broiler [3,7].

\subsection{PKC treatment to improve the digestibility}

There are lots of treatment available to breakdown the cellulose chain in PKC in order to make it more digestible. The mechanical, chemical and biological treatment of PKC appears to improve the nutritive values of PKC.

The choices of PKC treatment has been considered an important issue faced by nutritionists, and it has limited the manipulation of PKC to be used in the feed formulation. It has been reported that the maximum level of PKC that can be incorporated in the broiler diet is around $10 \%$. However, the treatment of the PKC via solid-state fermentation by cellulolytic bacteria may increase the inclusion of $\mathrm{PKC}$ in the broiler diet up to $15 \%$. 
A study by [9] on the PKC treated by enzyme produced by cellulolytic bacteria (Paenibacillus curdlanolyticus DSMZ 10248) via solid state fermentation and fed to broiler has found out that the birds fed with $1 \%$ of enzyme had significantly increase the feed intake and growth performance. In other study, the apparent metabolizable energy (AME) and ileal crude protein digestibility in broiler fed with $25 \%$ of enzyme treated PKC in the diet were significantly increased than control group [10]. Supplementation of NSP (e.g. xylanase) at concentration of $200 \mathrm{U} / \mathrm{kg}$ in the broiler diet incorporated with $20 \%$ of PKC has significantly increase the growth performance in the treated group than control [7]. Extrusion is another way of physical treatment on the PKC that can increased the nutritive value and broiler performance. A study by [11] reported that extrusion process on the PKC has increased the AME and CP digestibility by $6 \%$ and $32 \%$ respectively in broiler chicken fed with a basal diet supplemented with $20 \%$ PKC.

\section{Conclusion}

In summary, the use of alternative feedstuffs in poultry industry has received many attention nowadays because of their readily availability, nutritive value and a cheap source of protein and energy. Furthermore, the used of these non-conventional feedstuffs are not competing with humans as a source of food. At the same time, the used of PKC in the broiler diet can be considered as one of the promising sustainable feed resources as it can substitute certain portions of soybean and corn which will reduce the cost of broiler production.

\section{References}

1. A. Sharmila, A. R. Alimon, A. Kassim, M. N. Hezmee, A. A. Samsudin, Malaysian J. Anim. Sci. 17 (2014)

2. MPOB. https://mpob.gov.my/data-set

3. C. H. Chong, I. Zulkifli, R. Blair, Asian-Australas. J. Anim. Sci. 21 (2008)

4. M. Choct, G. Anisson, Br. Poult. Sci. 33 (1992)

5. D. Józefiak, A. Rutkowski, S. A. Martin, Anim. Feed Sci. Technol. 113 (2004)

6. M. Ramin, A. R. Alimon, M. Ivan, Livest. Res. Rural Dev. 22, 82 (2010)

7. A. Sharmila, A. Kassim, M. N. Hezmee, A. A. Samsudin, J. Anim. Poult. Sci. 3 (2014)

8. A. R. Alimon, Palm Oil Developments 40 (2004)

9. H. U. Zamani, T. C. Loh, H. L. Foo, A. A. Samsudin, M. I. Alshelmani, Int. J. Microbiol. Biotechnol. 2 (2017)

10. A. H. Hakim, I. Zulkifli, A. Soleimani Farjam, E. A. Awad, N. Abdullah, W. L. Chen, Ital. J. Anim. Sci. 19 (2020) 